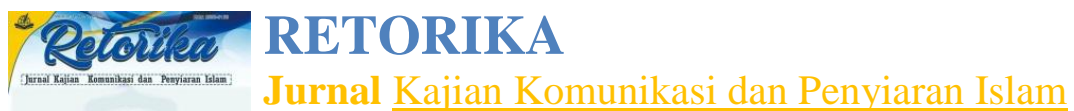

Volume 2, No. 22020

P-ISSN: 2655-5166

E-ISSN: 2715-2103

(6) Homepage : http://journal.iaimsinjai.ac.id/indeks.php/retorika

\title{
MEDIA SEBAGAI SALURAN DAKWAH, LEMBAGA SOSIAL DAN KOMERSIAL
}

\author{
Suriati1 \\ ${ }^{1}$ Institut Agama Islam Muhammadiyah Sinjai, \\ Jl.Sultan Hasanuddin, No. 20 Balangnipa, Sinjai \\ E-mail: suriatimarjan@gmail.com,Tlp: +6281355983665
}

\begin{abstract}
Abstrack
the use of preaching media is not a new thing in Islamic civilization, but the mastery of the media for some preachers is not as fast as the development of the media itself. In fact, the media of preaching can be said to be "wasilah" da'wah in Islam which is not only focused on a single media. This research discusses the topic of media as a da'wah channel, social and commercial institutions. In this study, researchers used a type of qualitative research. The type of this research is descriptive using qualitative methods. Then the approach used is library research. Based on the results of research and discussion in this study, da'wah is a noble activity for every Muslim to carry out amar ma'ruf nahi munkar, so that the ultimate goal of da'wah is created, namely forming khairul ummah. With the existence of media that can be used as a communication channel, both in the dakwah movement, social and commercial institutions are visual media, audio media, audio visual media, print media, and the internet. The role of the media as a channel for da'wah, social and commercial institutions is as a tool, intermediary and means used in communication activities that support the continuation of the process of delivering messages from communicants to the public effectively.
\end{abstract}

Keywords: Media, Da'wah Channels, Social Institutions, Commercial

\begin{abstract}
Abstrak
Penggunaan media dakwah bukan suatu perkara yang baru dalam peradaban Islam, namun penguasaan media bagi beberapa dai belum secepat dengan perkembangan media itu sendiri. Padahal, media dakwah dapat dikatakan sebagai "wasilah" dakwah dalam Islam yang tidak hanya tertumpu kepada suatu media saja. penelitian ini yaitu membahas masalah topik media sebagai saluran dakwah, lembaga social dan komersial.. Dalam penelitian ini, peneliti menggunakan jenis penelitian kualitatif. Adapun tipe penelitian ini bersifat deskriptif dengan menggunakan metode kualitatif. Kemudian pendekatan yang digunakan adalah penelitian pustaka. Berdasarkan hasil penelitian dan Pembahasan pada penelitian ini bahwa dakwah merupakan suatu aktivitas yang mulia bagi setiap muslim untuk melakukan amar ma'ruf nahi munkar, sehingga tercipta tujuan dakwah yang hakiki, yakni membentuk khairul ummah. Dengan adanya media yang dapat dijadikan sebagai saluran komunikasi, baik dalam gerakan dakwah, lembaga sosial maupn komersial adalah media visual, media audio, media audio visual, media cetak, dan internet. Peranan media sebagai saluran
\end{abstract}


"Retorra RETORIKA

Jurnal Kajian Komunikasi dan Penyiaran Islam

Volume 2, No. 22020

P-ISSN: 2655-5166

E-ISSN: 2715-2103

(2)

Homepage : http://journal.iaimsinjai.ac.id/indeks.php/retorika

dakwah, lembaga sosial, dan komersial adalah sebagai alat, perantara dan sarana yang digunakan dalam kegiatan komunikasi yang menjadi penunjang dalam kelangsungan proses penyampaian pesan dari komunikan kepada khalayak secara efektif.

Kata Kunci : Media, Saluran Dakwah, Lembaga Social, Komersial

\section{Pendahuluan}

Dakwah adalah kewajiban setiap muslim yang harus dilakukan secara berkesinambungan, yang bertujuan akhir mengubah perilaku manusia berdasarkan pengetahuan dan sikap yang benar yakni untuk membawa manusia mengabdi kepada Allah swt. secara total. Sebagai suatu aktivitas, dakwah berupaya mengubah suatu situasi tertentu kepada situasi yang lebih baik menurut ajaran Islam. Dengan kata lain dakwah, berarti menyampaikan konsepsi Islam kepada manusia mengenai pandangan dan tujuan hidup di dunia ini.

Tampaknya, dakwah yang dimaksudkan tersebut merupakan aktualisasi iman (teologis) yang dimanifestasikan dalam suatu sistem kegiatan manusia beriman secara sistematis, untuk memberikan sugesti cara berpikir dan bertindak dalam kerangka individu dan sosial sesuai ajaran Islam. Jadi, dakwah hendaknya ditujukan untuk memberikan dasar filosofis bagi eksistensi masyarakat baru, memberikan arah perubahan menuju tatanan masyarakat adil dan makmur yang diridhoi Allah swt. dan meletakkan Islam sebagai etos kerja yang dengan sendirinya menempatkan agama sebagai penggerak perubahan sosial.

Dakwah adalah usaha secara sadar yang dilaksanakan oleh individu/kelompok. Dakwah perlu dikelola secara profesional agar berhasil secara efektif dan efisien. Pengelolaan kegiatan dakwah memerlukan administrasi dan manajemen dakwah yang baik sehingga terjadi perubahan perilaku audience yang menjadi sasaran dakwah. Dengan demikian, dakwah adalah suatu proses yang kompleks. Proses dakwah terjadi karena adanya interaksi antara sejumlah unsur, 
"Retorra RETORIKA

Jurnall Kajian Komunikasi dan Penyiaran Islam

Volume 2, No. 22020

P-ISSN: 2655-5166

E-ISSN: 2715-2103

(6) Homepage : http://journal.iaimsinjai.ac.id/indeks.php/retorika

dimana unsur-unsur yang dimaksud meliputi;dai (komunikator) atau penyampai dakwah, penerima/pendengar, lingkungan dan sarana/media dakwah.

Unsur-unsur tersebut merupakan sebuah sistem yang saling mempengaruhi antara satu dengan yang lainnya dalam suatu aktivitas dakwah. Keberhasilan dakwah sangat ditentukan oleh peran dari semua unsur tersebut. Salah satu unsur yang sangat menunjang di dalam proses berlansungnya dakwah yang dikenal pula dengan istilah media dakwah (Marhalim, 2011).

Aktifitas dakwah saat ini tidak cukup dengan menggunakan media-media tradisional, seperti melalui ceramah-ceramah dan pengajian-pengajian yang masih menggunakan media komunikasi oral atau tutur. Penggunaan media-media komunikasi modern sesuai dengan tarap perkembangan daya fikir manusia harus dimanfaatkan sedemikian rupa, agar dakwah Islam lebih mengena sasaran dan tidak out of date. Apalagi diketahui perkembangan media yang berbasis teknologi mengalami akselerasi sedemikian cepat. Kondisi ini menuntut gerakan dakwah dapat menyesuaikan dengan akselerasi perkembangan media tersebut. jika tidak, maka dakwah akan tertinggal dan bahkan akan ditinggalkan oleh jamaahnya.

Setiap muslim diharapkan mengambil bagian dalam rangka pelaksanaan dakwah, yakni mengajak manusia ke jalan Allah untuk memperoleh kebahagiaan di dunia dan akhirat. M. Hidayat Nurwahid menegaskan bahwa apabila orang melaksanakan amr (perintah), menjauhi nahi (larangan), dan bertindak di dalam batas-batas Allah, mereka akan merasakan kebaikan sunnah rabbaniyah (Suriati, 2020).

Dalam melaksanakan agenda dakwah, pendakwah harus menggunakan media yang ada sesuai perkembangan zaman. Gelombang modenisasi pada masa kini memperlihatkan bahwa media merupakan salah satu sumber ilmu yang sangat dekat dengan manusia. Pada sisi inilah para dai harus mengambil manfaat terutama pada media sosial untuk menyampaikan pesan dakwah. Hal ini disebabkan, media seperti ini jamaah dapat melakukan interaksi langsung dengan sumber (dai) 
Volume 2, No. 22020

P-ISSN: 2655-5166

E-ISSN: 2715-2103

(2) Homepage : http://journal.iaimsinjai.ac.id/indeks.php/retorika

Oleh karena itu, tidak ada kata untuk tidak mengikuti perkembangan media yang bergerak sedemikan cepat tersebut. Dakwah harus memola gerakannya bersama perkembangan teknologi media. Konsekuensi logisnya dai harus melek dan mampu menggunakan media untuk dapat mengakselerasi penyampaian pesan-pesan dakwah kepada umat.

\section{Kajian Teori}

\subsection{Media, Dakwah, Lembaga Sosial, dan Komersial}

Kata media berasal dari bahasa latin "medius" yang secara harfiah berarti perantara atau pengantar. Dalam bahasa Arab media adalah pengantar (wasilah). Media sacara garis besar adalah manusia, materi, atau kejadian yang membangun kondisi yang membuat siswa mampu memperoleh pengetahuan, keterampilan atau sikap. Sedangkan menurut AECT (Association of education and communication technology), media adalah segala bentuk dan saluran yang digunakan untuk menyampaikan pesan atau informasi (Azhar, 2011). Kata sarana sering juga diartikan sama dengan "media" yang juga berarti "perantara". Secara etimologis sarana adalah segala sesuatu yang dipakai sebagai alat dalam mencapai maksud dan tujuan (Indonesia, 1990).

Secara terminologi, media dalam konteks komunikasi adalah alat atau sarana yang digunakan untuk menyampaikan pesan komunikator kepada khalayak (Cangara, 2000). Wilbur Schramm dalam Samsul Munir Amin, mendefinisikan media seagai teknologi informasi yang dapat digunakan dalam pengajaran (Amin \& Zirzis, 2009). Dalam bahasa arab media/wasilah yang bisa berarti al-wushlah, atattishad, yaitu segala hal yang dapat menghantarkan terciptannya kepada sesuatu yang dimaksud (Aliyudin, 2009).

Donald P. Ely dan Vernon S. Gerlach dalam Ahmad Rohani mengartikan media menjadi dua bagian :

a. Arti sempit, bahwa media itu berwujud : grafik, foto, alat mekanik, dan elektronik yang digunakan untuk menangkap, memproses serta menyampaikan informasi. 
Retorea RETORIKA

Jurnall Kajian Komunikasi dan Penyiaran Islam

Volume 2, No. 22020

P-ISSN: 2655-5166

E-ISSN: 2715-2103

(8) Homepage : http://journal.iaimsinjai.ac.id/indeks.php/retorika

b. Arti luas, media, yaitu kegiatan yang dapat menciptakan suatu kondisi, sehingga memungkinkan seseorang memperoleh pengetahuan, keterampilan, dan sikap yang baru (Rohani, 1997).

Dari beberapa pengertian di atas dapat diambil kesimpulan bahwa media adalah segala sesuatu, baik berupa benda, manusia, hasil teknologi bergerak maupun tidak bergerak yang dapat digunakan untuk menyalurkan pesan dari pengirim kepada penerima, sehingga dapat merangsang pikiran, perasaan, perhatian, dan minat serta perhatian khalayak sedemikian rupa, sehingga proses pengolahan informasi terjadi.

Da'wah secara etimologi, berasal dari kata da'a (دعا) fi'il madi dan yad'u (يدعو) fi 'il mudari' yang artinya memanggil, mengundang, mengajak, menyeru, dan mendorong (Munawir, 1997). Sedangkan arti dakwah secara terminologi yang dikemukakan oleh Syeikh Ali Mahfudz adalah mengajak manusia untuk mengerjakan kebaikan dan mengikuti petunjuk, menyuruh mereka berbuat baik dan melarang mereka dari perbuatan jelek agar mereka mendapat kebahagiaan di dunia dan akhirat (Rauf, 1987).

Berdasarkan pengertian tersebut dapat dipahami bahwa dakwah merupakan suatu aktivitas yang mulia bagi setiap muslim untuk melakukan amar ma'ruf nahi munkar, sehingga tercipta tujuan dakwah yang hakiki, yakni membentuk khairul ummah. Apalagi dakwah pada dasarnya merupakan suatu proses yang berkesinambungan yang ditanggung oleh para pengemban dakwah untuk mengukuhkan sasaran-sasaran dakwah agar masuk ke jalan Allah Swt. Secara bertahap menuju kehidupan yang Islami.

Menurut Yasmil Anwar dan Adang, lembaga secara sosiologis, dapat diartikan sebagai suatu format yang mantap, stabil, terstruktur, dan mapan (estabilished). Dalam pengertian ini lembaga sebagai suatu jaringan sarana hidup berisi peranan yang menjalankan fungsi masyarakat secara terus menerus dan berulang-ulang. Selanjutnya, lembaga sosial menurut Robert Mac Iver dan Charles H. Page dalam Yesmil Anwar dan Adang, mengartikan lembaga sosial sebagai tata cara atau prosedur yang telah diciptakan untuk mengatur hubungan antar-manusia yang 
"Retorra RETORIKA

Jurnall Kajian Komunikasi dan Penyiaran Islam

Volume 2, No. 22020

P-ISSN: 2655-5166

E-ISSN: 2715-2103

(운 Homepage : http://journal.iaimsinjai.ac.id/indeks.php/retorika

berkelompok dalam suatu kelompok kemasyarakatan yang dinamakan association. Selain itu, Alvin L. Bertrand dalam Dewi Wulan Sari, menyatakan bahwa Institusiinstitusi sosial pada hakikatnya adalah kumpulan-kumpulan dari norma-norma sosial (struktur-struktur sosial) yang telah diciptakan untuk melaksanakan fungsi masyarakat. Institusi-institusi ini meliputi kumpulan-kumpulan norma-norma dan bukan norma-norma yang berdiri sendiri-sendiri (Nurhayati, 2015).

Berdasarkan pengertian tersebut dapat dipahami bahwa lembaga sosial adalah suatu format yang mantap, stabil, terstruktur, dan mapan di dalam masyarakat yang melakukan aktivitas berdasarkan posisi masing-masing individu atau kelompok, dalam suatu sistem hubungan sosial yang terorganisir atau teratur yang memperlihatkan adanya nilai-nilai, norma, peraturan, dan cara-cara berhubungan satu sama lain, yang diatur bersama guna memenuhi kebutuhan manusia dalam suatu masyarakat tertentu.

Menurut Black's Law Dictionary, definisi dari "commerce" adalah "the exchange of services, goods, productions, or property of any kind (maulidi, 2015). Berdasarkan pengertian ini, komersial dapat artikan sebagai kegiatan yang mencakup kepada pertukaran pelayanan, barang, produksi atau properti. Oleh karena itu, semua jenis kegiatan komersial pada dasarnya bertujuan untuk keuntungan (the purpose to make profit) atau setidaknya untuk membuat sebuah keuntungan yang layak dalam inventasi (to make a reasonable return on investment).

Bertolak dari pengertian tersebut, pengertian komersial dapat pahami sebagai kegiatan yang dilakukan untuk mendapatkan keuntungan baik, secara langsung maupun tidak langsung. Dalam hal ini termasuk semua kegiatan yang awalnya tidak mendapatkan keuntungan tetapi setelah beberapa tahap selanjutnya kegiatan tersebut mendapakan keuntungan ; itu juga termasuk komersialisasi.

Berdasarkan paparan yang telah dikemukakan sebelumnya, penulis berkesimpulan bahwa dakwah, lembaga sosial dan komersial memiliki tujuan yang sama pada tataran objek. Objek yang dimaksud tersebut adalah manusia. Hal tersebut ingin mengajak dan memengaruhi manusia agar tertarik dengan tawaran-tawaran 
Returea RETORIKA

Jurnall Kajian Komunikasi dan Penyiaran Islam

Volume 2, No. 22020

P-ISSN: 2655-5166

E-ISSN: 2715-2103

(2)

Homepage : http://journal.iaimsinjai.ac.id/indeks.php/retorika

yang disampaikannya. Hanya saja tujuan akhir memengaruhinya yang berbeda antara satu dengan lainnya. Dakwah bertujuan agar manusia berada dalam tuntutan agama, lembaga sosial bertujuan untuk meneruskan nilai dan program-program lembaganya (terutama kepada anggotanya), dan lembaga komersial bertujuan untuk meraup keuntungan yang sebesar-besarnya.

Oleh karena itu, dalam mencapai tujuan masing secara efektif dan efisien, ketiga-tiganya mmerlukan media, baik media audio, media visual, maupun media audio-visual ; mulai yang paling sederhana sampai kepada media yang paling mutakhir. Media dalam konteks ini adalah segala sesuatu yang dipergunakan atau menjadi menunjang dalam berlangsungnya pesan dari komunikan kepada kalayak. Atau dengan kata lain segala sesuatu yang dapat menjadi penunjang/alat dalam proses memengaruhi, mengajak dan sebagainya yang berfungsi mengefektifkan penyampaian ide (pesan) dari komunikator kepada komunikan (khalayak).

\subsection{Bentuk-Bentuk Media}

\section{Bentuk Media}

Bedasarkan pengertian media sebelumnya, yaitu segala sesuatu yang menjadi perantara, maka ada beberapa macam media yang digunakan dalam suatu proses komunikasi. Secara umum media-media benda yang dapat digunakan sebagai media dakwah di kelompokan pada:
a. Media Visual
b. Media Audio
c. Media Audio Visual
d. Media Cetak (Amin \& Zirzis, 2009).

\section{1) Media Visual}

Media komunikasi visual merupakan alat komunikasi yang dapat digunakan dengan menggunakan indra penglihatan dalam menangkap datanya. Jadi matalah yang paling berperan dalam pengembangan pesan atau data yang dikirim komunikator. Media komunikasi yang berwujud alat yang menggunakan penglihatan sebagai pokok persoalannya terdiri dari jenis alat komunikasi yang sangat komplit. 
Returea RETORIKA

Jurnall Kajian Komunikasi dan Penyiaran Islam

Volume 2, No. 22020

P-ISSN: 2655-5166

E-ISSN: 2715-2103

(6) Homepage : http://journal.iaimsinjai.ac.id/indeks.php/retorika

Media visual tersebut meliputi: film slide, OHP, gambar foto diam, dan computer (Ali Aziz, 2004).

\section{2) Media Auditif}

Media auditif merupakan alat komunikasi yang berbentuk teknologi canggih yang berwujud hardware, media auditif dapat ditangkap melalui indra pendengaran. Perangkat auditif ini pada umumnya adalah alat-alat yang diopersioanalkan sebagai sarana penunjang kegiatan dakwah. Penyampaian materi dakwah melalui media auditif ini menyebabkan dapat terjangkaunya sasaran dakwah dalam jarak jauh. Alatalat auditif ini sangat efektif untuk penyebaran informasi atau penyampaian kegiatan dakwah yang cenderung persuasif. Alat-alat ini meliputi; radio, tape recorder, telpon dan telegram.

\section{3) Media Audio Visual}

Media audio visual merupakan perangkat yang dapat ditangkap melalui indra pendengaran maupun penglihatan. Apabila dibandingkan dengan media yang telah dikemukakan sebelumnya, ternyata media audiovisual lebih paripurna, sebab media ini dapat dimanfaatkan oleh semua golongan masyarakat. Termasuk dalam media ini; movie film, TV, video, dan media cetak.

\section{4) Media Cetak}

Media cetak (printed publication) adalah media untuk menyampaikan informasi melalui tulisan yang tercetak. Media cetak merupakan media yang sudah lama dikenal dan mudah dijumpai di mana-mana. Media ini amat besar manfaatnya, sebab ia termasuk dari beberapa media masa pembentuk opini masyarakat, ia hampir bisa disebut "makanan pokok" masyarakat mendambakan informasi dan seelalu dapat mengikuti perkembangan dunia. Dakwah melalui media ini dapat berbentuk beritaberita Islam, penulis dan artikel-artikel Islam dan sebagainya. Adapun yang termasuk dalam media cetak antara lain buku, surat kabar, majalah, bulletin, brosur, dan lainlain. 
Returea RETORIKA

Jurnall Kajian Komunikasi dan Penyiaran Islam

Volume 2, No. 22020

P-ISSN: 2655-5166

E-ISSN: 2715-2103

(1)

Homepage : http://journal.iaimsinjai.ac.id/indeks.php/retorika

\section{5) Internet}

Semakin berkembangnya jaman, di era yang serba teknologi ini, bukanlah hal yang aneh lagi jika semakin banyak orang yang mulai menggunakan internet. Semuanya serba online, mulai dari panggilan ojek, asisten, hingga mencari pekerjaan paruh waktu maupun fulltime. Hal ini juga harus diterima sebagai media yang paling canggih dan berkembang dengan sangat cepat yang sering disebut sebagai zaman cyber karena segalanya menggunakan internet. Media ini juga merupakan saluran komunikasi terbesar dan yang paling banyak digunakan oleh khalayak.

Melalui internet sebagai media khalayak_dapat berkomunikasi dengan lancar, cepat, efektif, dan efisien. Internet juga memiliki jejaring sosial yang sangat beragam sepertifacebook, instagram, twitter, dan lain-lain yang dapat memberikan jangkauan yang luas dan cepat (Heru, 2017).

\section{Metode}

Penelitian sebagai upaya untuk memoperoleh kebenaran, harus disadari oleh proses berpikir ilmiah yang dituangkan dalam metode ilmiah. (Noor Juliansyah 2001:22). Penentuan suatu metode yang digunakan dalam suatu penelitian akan menentukan bagaimana hasil dari keabsahan dan tingkat kebenaran hasil penelitian. Oleh karena itu dalam penelitian ini peneliti berusaha mengurai segala permasalahan mengenai media sebagai saluran dakwah, lembaga sosial dan komersial (Musliadi, 2020).

Penelitian yang dipakai penulis dalam tulisan ini adalah penelitian kualitatif.

Menurut Lexi J. Moleong (2010:6) mengatakan penelitian kualitatif yaitu penelitian yang bermaksud untuk memahami fenomena tentang apa yang dialami oleh subyek penelitian. misalnya prilaku, persepsi, motivasi, tindakan dan lain-lain secara holistik serta dengan cara deskripsi dalam bentuk kata-kata dan bahasa, pada suatu konteks khusus yang alamiah dan dengan memanfaatkan berbagai metode alamiah (Sinjai \& Suriati, 2020). 
Volume 2, No. 22020

P-ISSN: 2655-5166

E-ISSN: 2715-2103

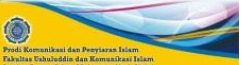

Homepage : http://journal.iaimsinjai.ac.id/indeks.php/retorika

Metode yang digunakan dalam kajian ini menggunakan metode atau pendekatan kepustakaan (library research), Studi pustaka atau kepustakaan dapat diartikan sebagai serangkaian kegiatan yang berkenaan dengan metode pengumpulan data pustaka, membaca dan mencatat serta mengolah bahan penelitian (Zed, 2014). Dalam penelitian studi pustaka setidaknya ada empat ciri utama yang penulis perlu perhatikan menurud Zed diantaranya : Pertama, bahwa penulis atau peneliti berhadapan langsung dengan teks (nash) atau data angka, bukan dengan pengetahuan langsung dari lapangan. Kedua, data pustaka bersifat "siap pakai" artinya peniliti tidak terjung langsung kelapangan karena peneliti berhadapan langsung dengan sumber data yang ada di perpustakaan. Ketiga, bahwa data pustaka umumnya adalah sumber sekunder, dalam arti bahwa peneliti memperoleh bahan atau data dari tangan kedua dan bukan data orisinil dari data pertama di lapangan. Keempat, bahwa kondisi data pustaka tidak dibatasi oleh runga dan waktu (Asriadi, 2020).

\section{Hasil dan Pembahasan}

\subsection{Peranan Media Sebagai Saluran Dakwah, Lembaga Sosial dan Komersial}

\section{a. Peranan media dakwah}

Pada zaman modern seperti sekarang ini, dengan banyaknya media yang ada, maka da'i harus dapat memilih media yang paling efektif untuk mencapai tujuan dakwah. Tentunya dengan memilih yang tepat atau dengan prinsip-prinsip media. Adapun yang menjadi masalah pada tataran ini adalah masalah memilih. Memilih tentu saja mengandung kosekuensi mengetahui dan menguasai cara memanfaatkan potensi yang dipilihnya. Tidak hanya memilih untuk disimpan atau dibiarkan saja. Karena sekarang adalah era globalisasi informasi, artinya di era tersebut terjadi penghilangan batas ruang dan waktu dari hasil perkembangan teknologi komunikasi. Masalah teknologi komunikasi menjadi penting untuk diupayakan agar para da'i menguasainya, karena pada hakikatnya dakwah adalah proses komunikasi baik media visual, audio, dan lebih penting lagi media audio visual, televisi, dan internet.

Dakwah sebagai suatu kegiatan komunikasi keagamaan dihadapkan kepada perkembangan dan kemajuan teknlogi komunikasi yang semakin canggih, 
Retorter RETORIKA

Jurnall Kajian Komunikasi dan Penyiaran Islam

Volume 2, No. 22020

P-ISSN: 2655-5166

E-ISSN: 2715-2103

(0) Homepage : http://journal.iaimsinjai.ac.id/indeks.php/retorika

memerlukan suatu adapasi terhadap kemajuan itu. Artinya dakwah dituntut untuk dikemas dengan terapan media komunikasi sesuai dengan aneka mad'u (komunikan) yang dihadapi (Bahri, 1997). Laju perkembangan zaman berpacu dengan tingkat kemajuan ilmu pengetahuan dan teknologi, tidak terkecuali teknologi komunikasi yang merupakan suatu sarana yang menghubungkan suatu masyarakat dengan masyarakat di bumi lain. Kecanggihan teknologi komunikasi ikut memengaruhi seluruh aspek kehidupan manusia termasuk di dalamnya kegiatan dakwah sebagai salah satu pola penyampaian informasi dan upaya transfer ilmu pengethauan. Hal tersebut menunjukkan bahwa proses dakwah bisa terjadi dengan menggunakan berbgai sarana/media, karena perkembangan ilmu pengetahuan dan teknologi sangat memungkinkan hal itu. Dalam suatu proses dakwah, seorang juru dakwah (da'i) dapat menggunakan berbagai sarana atau media. Salah satu unsur keberhasilan dalam berdakwah adalah kepandaian seorang da'i dalam memilih dan menggunakan sarana atau media yang ada (Sasono, 1998).

Sebagai bahan perenungan, penulis mengangkat salah ayat untuk dijadikan sebagai referensi dalam menyikapi perkembangan media saat ini, yaitu QS. Al-Qalam (68) $; 1$ :

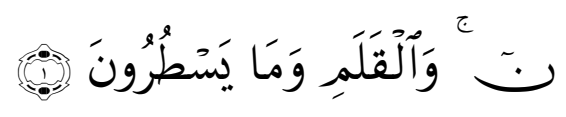

Terjemahnya :

Nun, demi kalam dan apa yang mereka tulis.

Pada awal surat ini, Allah bersumpah dengan nun dan qalam. Al-Qalam/pena dalam arti sempit dimaknai sebagai pena tertentu, ada juga yang memahaminya secara umum, yakni alat tulis apapun, termasuk komputer canggih sekalipun. M. Quraish Shihab, memahaminya secara umum lebih tepat dan ini sejalan dengan perintah membaca yang merupakan wahyu utama. Seperti dalam surat Iqra' (Shihab, 2002). 
Volume 2, No. 22020

P-ISSN: 2655-5166

E-ISSN: 2715-2103

(2) Homepage : http://journal.iaimsinjai.ac.id/indeks.php/retorika

Jika ditelaah, kata wa ma yasthurun/dan apa yang mereka tulis memberikan penegasan bahwa siapapun umat Islam harus menulis agar tulisan-tulisan tersebut dapat dibaca oleh siapapun. Apalagi jika dikaitkan dengan zaman sekarang ini, dakwah tidak hanya diberikan di atas mimbar dengan bahasa lisan, tetapi dakwah harus bergerak seiring dengan akselerasi media yang sangat cepat. Dengan demikian, seorang da'i harus dapat memilih media yang paling efektif untuk mencapai tujuan dakwah. Hal ini disebabkan khalayak telah memasuki era globalisasi informasi yang telah menghilangkan batas ruang dan waktu, sehingga mau atau tidak dakwah harus masuk untuk menguasai dan memenuhi langit dan angkasa ini dengan misi ilahiyah yang dikemas dalam pesan-pesan dakwah.

\section{b. Peran media pada lembaga sosial}

Lembaga sosia sebagaimana yang telah dijelaskan sebelumnya, berorientasi pada khalayak, terutama pada anggota lembaga dalam rangka menguatkan sistem melalui penyampaian informasi. Selain itu, beberapa lembaga juga turut mengambil bagian untuk melakukan sosialisasi program-program positif yang harus dilakukan. Atas dasar inilah lembaga sosial juga mengakomodasi dan menggunakan media dalam segala bentuknya sebagai basis pergerakannya.

Media sosial adalah bentuk komunikasi elektronik (seperti website untuk jejaring sosial dan microblogging) merupakan salah satu media yang banyak dipergunakan untuk membangun komunitas online untuk berbagi informasi, ide, pesan-pesan personal dan konten lainnya (seperti video). Para anggota lembaga sosial berbicara, berpartisipasi, berbagi, berjejaring dan ditandai dengan aktivitas online. Sebagian besar media sosial mendorong pengguna untuk berdiskusi, memberikan umpan balik, voting, komentar dan berbagi informasi sesuai dengan minatnya masing-masing (Kurniasih, 2013).

Menyikapi hal tersebut, pada tataran ini, lembaga sosial harus sadar bahwa media sosial sering bergerak liar di luar kendali pihak-pihak yang terkait. Oleh karena itu, lembaga sosial harus tetap melakukan control atas penggunaan media yang berbasis teknologi ini. Paling tidak lembaga harus memiliki kemampuan mengelola 
"Retorra RETORIKA

Jurnall Kajian Komunikasi dan Penyiaran Islam

Volume 2, No. 22020

P-ISSN: 2655-5166

E-ISSN: 2715-2103

(웅 Homepage : http://journal.iaimsinjai.ac.id/indeks.php/retorika

media sosial agar informasi-informasi yang berkaitan dengan lembaga penaung dapat tersampaikan dengan baik kepada khalayak terutama kepada anggota. Selain itu, lembaga sosial juga harus mampu mengelola berbagai sumber informasi dan saluran komunikasi secara efektif, agar informasi yang seharusnya diketahui oleh masyarakat dapat sampai kepada publik dengan tepat.

\section{c. Peranan media bagi lembaga komersial}

Pada bagian terdahulu telah dijelaskan orientasi akhir bagi lembaga komersial, yaitu meraup keuntungan sebesar-besarnya. Oleh karena itu, salah satu prinsip yang perlu diperhatikan oleh lembaga komersial adalah pemasaran. Pemasaran merupakan proses mengenali segmentasi pasar, target pasar, dan bauran pemasaran. Dengan hal tersebut, pemasaran akan fokus terhadap tugas yang dimilikinya, yaitu dengan mengetahui semua keadaan yang terjadi pada pasar. Selanjutnya, mulailah melakukan riset dengan benar sehingga pemasaran mendapatkan peluang bagus untuk menjual atau mempromosikan produk melalui media (Morissan, 2008).

Strategi pemasaran modern diperlukan adanya sebuah inovasi atau terobosan baru dalam dunia pemasaran. Hal ini terjadi pada bentuk kemasan sebuah produk dibuat menarik dan penetapan harga dibuat terjangkau sesuai dengan kebutuhan konsumen. Maka dari itu, Strategi pemasaran merupakan pernyataan (baik implisit maupun eksplisit) mengenai suatu merk atau produk dalam mencapai tujuannya (Tjiptono, 2008).

Melali pendekatan laba yang sebanyak-banyaknya, maka lembaga komersial memanfaatkan media untuk melakukan pemasaran. Media yang paling sering menjadi plihan adalah media online. Hal ini disebabkan media online tidak memerlukan biaya banyak, tidak memerlukan tempat yang luas, dan tidak membutuhkan waktu dan tenaga yang banyak. Bapak marketing dunia Philip Kotler mengatakan pemasaran sekarang sudah beralih konsep tradisional yang terkenal dengan sales door to door menjadi revolusi digital, dimana perdagangan atau trading sudah hitungan detik (Halim, 2013). Dalam hitungan detik transaksi dapat dilakukan seperti situs terbesar 
"Retorra RETORIKA

Jurnall Kajian Komunikasi dan Penyiaran Islam

Volume 2, No. 22020

P-ISSN: 2655-5166

E-ISSN: 2715-2103

Q

Homepage : http://journal.iaimsinjai.ac.id/indeks.php/retorika

di dunia amazon.com yang dalam setahun membukukan pendapatan bersih sekitar 6 triliun rupiah (Halim, 2013).

Jenis media promosi yang sering digunakan untuk mempengaruhi keputusan khalayak untuk membeli adalah media onlineshop. Sebagai contoh, media promosi berbentuk sosial media yang saat ini sering digunakan dalam e-promotion adalah instagram, path, Facebook, dan twitter. Salah satu bentuk komunikasi yang dilakukan perusahaan dalam pemasaran adalah melakukan kegiatan promosi yang bertujuan untuk memperkenalkan, meyakinkan, dan membujuk konsumen sehingga konsumen tertarik untuk menggunakan produk tersebut (Tjiptono, 2008).

Oleh karena itu, dapat dipahami bahwa tujuan promosi bersifat memengaruhi konsumen dan pada akhirnya mengahasilkan transaksi penjualan. Promosi adalah suatu bentuk komunikasi pemasaran, yaitu aktivitas pemasaran yang berusaha menyebarkan informasi, memengaruhi dan mengingatkan pasar sasaran atas perusahaan dan produk agar bersedia menerima, membeli, dan loyal pada produk yang ditawarkan.

\section{Simpulan}

Setelah membahas pokok masalah yang diangkat dalam makalah ini, penulis berkesimpulan bahwa, Media adalah segala sesuatu, baik berupa benda, manusia, hasil teknologi bergerak maupun tidak bergerak yang dapat digunakan untuk menyalurkan pesan dari pengirim kepada penerima, sehingga dapat merangsang pikiran, perasaan, perhatian, dan minat serta perhatian khalayak sedemikian rupa, sehingga proses pengolahan informasi terjadi. Kemudian dakwah merupakan suatu aktivitas yang mulia bagi setiap muslim untuk melakukan amar ma'ruf nahi munkar, sehingga tercipta tujuan dakwah yang hakiki, yakni membentuk khairul ummah. Selanjutnya, Lembaga sosial adalah suatu format yang mantap, stabil, terstruktur, dan mapan di dalam masyarakat yang melakukan aktivitas berdasarkan posisi masingmasing individu atau kelompok, dalam suatu sistem hubungan sosial yang terorganisir atau teratur yang memperlihatkan adanya nilai-nilai, norma, peraturan, dan cara-cara berhubungan satu sama lain, yang diatur bersama guna memenuhi 
Returea RETORIKA

Jurnall Kajian Komunikasi dan Penyiaran Islam

Volume 2, No. 22020

P-ISSN: 2655-5166

E-ISSN: 2715-2103

(2)

Homepage : http://journal.iaimsinjai.ac.id/indeks.php/retorika

kebutuhan manusia dalam suatu masyarakat tertentu. sedangkan komersial dapat pahami sebagai kegiatan yang dilakukan untuk mendapatkan keuntungan baik, secara langsung maupun tidak langsung. Bentuk-bentuk media yang dapat dijadikan sebagai saluran komunikasi, baik dalam gerakan dakwah, lembaga sosial maupn komersial adalah media visual, media audio, media audio visual, media cetak, dan internet. Peranan media sebagai saluran dakwah, lembaga sosial, dan komersial adalah sebagai alat, perantara dan sarana yang digunakan dalam kegiatan komunikasi yang menjadi penunjang dalam kelangsungan proses penyampaian pesan dari komunikan kepada khalayak secara efektif.

\section{Daftar Pustaka}

Ali Aziz, M. (2004). Ilmu Dakwah Edisi Revisi. Jakarta: Kencana.

Aliyudin, E. A. S. (2009). Dasar-Dasar Ilmu Dakwah. Bandung: Widya Padjajaran. Amin, S. M., \& Zirzis, A. (2009). Ilmu dakwah. Amzah.

Asriadi. (2020). Retorika sebagai Ilmu Komunikasi dalam Berdakwah. Al-MUNZIR, 13(1), 89-106.

Azhar, A. (2011). Media pembelajaran. Jakarta: Rajawali Pers.

Bahri, M. (1997). Ghazali, Membangun Kerangka Dasar Ilmu Komunikasi Dakwah. Jakarta: Pedoman Ilmu Jaya.

Cangara, H. (2000). Pengantar Ilmu Komunikasi. cetakan kedua. Radja Grafindo Persada Jakarta.

Halim, C. (2013). Tip Praktis Promosi Online untuk Berbagai Event. Elex Media Komputindo.

Heru. (2017). 7 Media Komunikasi Modern - Penjelasan dan Fungsinya. Https://Pakarkomunikasi.Com/. https://pakarkomunikasi.com/mediakomunikasi-modern

Indonesia, K. B. B. (1990). Depdikbud dan Balai Pustaka, Cetakan ke IV. Jakarta.

Kurniasih, N. (2013). Penggunaan Media Sosial bagi Humas di Lembaga Pemerintah. https://doi.org/10.13140/RG.2.2.15820.41609 
"Retorra RETORIKA

Jurnall Kajian Komunikasi dan Penyiaran Islam

Volume 2, No. 22020

P-ISSN: 2655-5166

E-ISSN: 2715-2103

(9)

Homepage : http://journal.iaimsinjai.ac.id/indeks.php/retorika

Marhalim.

(2011).

MEDIA

DALAM

BERDAKWAH.

Http://Ruangruhani.Blogspot.Com/.

http://ruangruhani.blogspot.com/2011/05/media-dalam-berdakwah.html

maulidi. (2015). Kegiatan Penamaan Kawah di Planet Mars oleh Perusahaan

Uwingu sebagai Kegiatan Komersial di Ruang Angkasa dan Akibat Hukumnya

Berdasarkan Hukum Ruang Angkasa Internasional. http://repository.unisba.ac.id/bitstream/handle/123456789/4519/06bab2_maulidi _10040012061_skr_2015.pdf?sequence=6\&isAllowed=y

Morissan, M. A. (2008). Manajemen Media Penyiaran. Prenada Media Grup.

Munawir, A. W. (1997). Kamus al-Munawir Arab Indonesia, edisi II. Pustaka Progresif: Surabaya.

Musliadi, M. (2020). Strategi Komunikasi Strategi Komunikasi Pada Pelayanan Kesehatan Masyarakat Umum (Studi Kasus Rumah Sakit Sultan DG. Radja Bulukumba). RETORIKA: Jurnal Kajian Komunikasi Dan Penyiaran Islam, 2(1), 1-22.

Nurhayati. (2015). PERAN LEMBAGA SOSIAL TERHADAP PEMBINAAN MORAL REMAJA DI DESA BANGUNREJO DUSUN 1 KECAMATAN GUNUNG SUGIH KABUPATEN LAMPUNG TENGAH. http://digilib.unila.ac.id/8712/15/BAB II.pdf

Rauf, A. K. S. A. (1987). Dirasah Fid Dakwah Al-Islamiyah. Kairo: Dar El-Tiba'ah al-Mahmadiyah.

Rohani, A. (1997). Media Instruksional Edukatif, Cet: I; Jakarta: PT. Rineka Cipta.

Sasono, A. (1998). Solusi Islam atas problematika umat: ekonomi, pendidikan, dan dakwah. Gema Insani.

Shihab, M. Q. (2002). Tafsir al-misbah. Jakarta: Lentera Hati, 2.

Sinjai, M., \& Suriati, S. (2020). Persepsi Mahasiswa IAIM Sinjai Terhadap Fenomena Video Prank di Media Sosial. RETORIKA: Jurnal Kajian Komunikasi Dan Penyiaran Islam, 2(1), 23-35. https://doi.org/10.47435/retorika.v2i1.227 
Rerorter RETORIKA

Jurnall Kajian Komunikasi dan Penyiaran Islam

Volume 2, No. 22020

P-ISSN: 2655-5166

E-ISSN: 2715-2103

(9) If)

Homepage : http://journal.iaimsinjai.ac.id/indeks.php/retorika

Suriati, S. (2020). Pola Komunikasi Dakwah Wahdah Islamiyah di Kabupaten Sinjai,

Sulawesi Selatan. Jurnal SMART (Studi Masyarakat, Religi, Dan Tradisi), 6(1),

81-95. https://doi.org/10.18784/smart.v6i1.927

Tjiptono, F. (2008). Strategi Pemasaran Edisi 3. Yogyakarta: Andi. 